\title{
CHARACTERIZATION OF LAMPROITES FROM PARAGUAY (SOUTH AMERICA).
}

\author{
Preser, I.B.
}

Dep. Geologia, Facultad de Ciencias Exactas y Naturales, U.N.A.C.C, 1039, Assunción-Paraguay.

Lamproites were found in the ultrapotassic Guairá-Paraguarí Province, $80 \mathrm{~km} \mathrm{SE}$ from the capital city of Asunción (south Central Paraguay). This region constitutes the western portion of the intracratonic Paraná Basin and was affected by potassic to ultrapotassic magmatism of mesozoic age ( $133 \mathrm{My}$ ), occuring mainly within the so-called Asunción rift.

The recognized lamproite bodies are plugs, dikes and pipe-like, and associated with other volcanic rocks such as basanites (leucite-bearing alkalibasalts), damkjernites, ouachitites, sannaites, peridotites microxenolith-bearing monchiquites and cocites, as well as intrusive rocks as ijolites, peridotites microxenolith-bearing shonkinites and carbonatites.

The "Ñande Yara gracia" (ÑYr) plug is about $200 \mathrm{~m}$ diameter lamproitic in character pipe-like and intruded into leucite-bearing basaltic rocks. Its exposure is masked by soil, vegetation and blocks of neighbouring volcanic alkaline rocks.

The NYgr rocks in hand specimen, is dark gray in colour and porphyritic due the presence of abundant leucite crystals with a glomeroporphyritic structure (up to $10 \mathrm{~mm}$ in diameter), some diopside prisms, serpentine (after olivine) crystals (up to $1 \mathrm{~mm}$ in diameter); occasional minute vesicle are filled with zeolites.

LEUCITE is present as octogonal or rounded twinned phenocrysts with pleochroic inclusions (purple to lemon canario), zoned and elongated K,Ti-richterite (with margins altered to a light green-yellow secondary phase, similar to that described by Mitchell and Lewis, 1983 in the Prairie Creek olivine-lamproite) and also diopside, serpentine (after olivine), rectangular opaques, prismaticlance-like opaque (jeppeite) associated with priderite, and devitrified glass. Other phenocrysts are pale yellow-green zoned an twinned DIOPSIDE laths; idiomorphic serpentine (after OLIVINE); and rectangular to allotriomorphic OPAQUES (up to $1 \mathrm{~mm}$ ) the groundmass consists of colourless diopside prisms, rectangular opaques idiomorphic shchervakovite, some K,Ti-richterite, phlogopite, apatite, priderite, wadeite and lucasite; plus intersticial sanidine and devitrified glass.

The rock can be classified as a OLIVINE-BEARING LEUCITE LAMPROITE (according to Scott-Smith and Skinner, 1984) or as a LEUCITE DIOPSIDE LAMPROITE = CEDRICITE (following Wade and Prider, 1940; Mitchell, 1984). This lamproite is similar to the "West Kimberley" lamproites and also Kapamba lamproites (cf. Scott-Smith and others, 1988).

Orange to deep red and red-wine to lilac garnets, $\mathrm{Cr}$-diopside, ilmenite, $\mathrm{Cr}$-spinels and diamonds (dodecahedrons to rounded, irregular, macles and aggregates) were obtained from the NYgr pipe and overlying soil.

The NYgr rock chemistry shows high $\mathrm{TiO}_{2}, \mathrm{MgO}$ and high ratios of $\mathrm{K}_{2} \mathrm{O} / \mathrm{Na}_{2} \mathrm{O}$, $\mathrm{K}_{2} \mathrm{O} / \mathrm{Al}_{2} \mathrm{O}_{3}$. The $\mathrm{CaO}, \mathrm{Al}_{2} \mathrm{O}_{3}$ and $\mathrm{Na}_{2} \mathrm{O}$ are low, LREE/HREE and LILE/HFSE enrichment is similar to the "West Kimberley" ultrapotassic rock type. 
Thus, the Guairá-Paraguarí Ultrapotassic Province is another potential diamondiferous province.

\section{REFERENCES}

MITCHELL,R.H. 1985. A review of the mineralogy of lamproites. Trans. Geol. Soc. S. Afr., 88: 411-437.

MITCHELL,R.H. and LEWIS,R.D. 1983. Priderite-bearing xenoliths from the Prairie Creek mica peridotite, Arkansas. Canadian Mineralogist, 21: 59-64.

SCOTT-SMITH,B.H. and SKINNER,E.M.W. 1984. Diamondiferous lamproites. Journal of Geology, 92: 433438.

SCOTT-SMITH,B.H.; SKINNER,E.M.W.; LONEY,P.E. 1988. The Kapamba lamproites of Luangwa Valley, eastern Zambia. In Kimberlites and related rocks: their mineralogy, petrology and chemistry. Geol. Soc. Aust. Spec. Publ. 14,p. 189-205.

WADE,A. and PRIDER,R.T. 1940. The leucite-bearing rocks of the west kimberley area, Western Australia. Quart. J. Geol.Soc. London, 96: 39-98. 